\title{
Apolo-Prometeu e Dioniso: dois perfis mitológicos do "homem das 24 horas" de Gaston Bachelard
}

\author{
Alexander de Freitas
}

Universidade de São Paulo

Para Beatriz Fétizon que, como Ariadne, entregoume o fio condutor para que eu não me perdesse...

\section{Resumo}

Gaston Bachelard (1884-1962), um filósofo como ele se auto-denomina de "dupla natureza", pensador de campos do conhecimento tão díspares como a epistemologia da ciência e a metafísica da imaginação poética, reclama uma leitura da dualidade e da complexidade da sua vida e obra. Desse modo, o objetivo deste artigo é investigar a relação dialógica entre a epistemologia da ciência e a metafísica da imaginação poética, dois delineamentos opostos, concorrentes e complementares da filosofia de Bachelard, freqüentemente expressos pelos epítetos "diurno" e "noturno". Para estudarmos a relação entre essas duas vertentes do pensamento de Bachelard, partimos da análise da ambivalência dos seguintes pares de conceitos: obstáculo epistemológico \&t imaginação material e psicanálise do conhecimento \&t método fenomenológico, que estruturam, teoricamente no primeiro par e, metodologicamente no segundo, sua epistemologia da ciência e sua metafísica da imaginação poética. Os dados obtidos permitem concluir que a sutura entre a epistemologia científica e a metafísica poética de Bachelard está representada em seu conceito de "homem das 24 horas". Esse homem complexo, andrógino, leitor e pensador das idéias científicas e da gênese poética, parece ser uma imagem conciliadora das antinomias expressas nas faces diurna e noturna da filosofia bachelardiana. Ampliando a análise imagética do "homem das 24 horas", por meio de uma hermenêutica mitanalítica, encontramos as duas faces da filosofia de Bachelard configuradas, respectivamente, pelos mitos de Apolo-Prometeu e Dioniso.

\section{Palavras-chave}

Gaston Bachelard - Epistemologia - Metafísica da imaginação poética - "homem das 24 horas".

Correspondência: 


\title{
Apollo-Prometheus and Dionysus: two mythological profiles of Gaston Bachelard's "24-hour man"
}

\author{
Alexander de Freitas \\ Universidade de São Paulo
}

To Beatriz Fétizon who, like Ariadne, gave me the guiding thread to prevent me from getting lost...

\begin{abstract}
Gaston Bachelard (1884-1962), a philosopher who declared himself to be of a "double nature", a thinker in fields of knowledge as diverse as the epistemology of science and the metaphysics of poetic imagination, demands a reading of the duality and complexity of his life and work. The purpose of this article is therefore to investigate the dialogical relationship between the epistemology of science and the metaphysics of poetic imagination, two opposed, competing, and complementary traits of Bachelard's philosophy, often expressed by the epithets of "diurnal" and "nocturnal". To study the relationship between these two directions in Bachelard's thought, we start from the analysis of the ambivalence of the following pairs of concepts: epistemological obstacle \&t material imagination, and psychoanalysis of knowledge \&t phenomenological method, which structure, theoretically in the case of the former pair, and methodologically in the case of the latter pair, his epistemology of science and his metaphysics of poetic imagination. The results allow us to say that the joining of Bachelard's scientific epistemology and poetical metaphysics is represented in his concept of the "24-hour man". This complex, androgynous man, reader and thinker of the scientific ideas and of the poetical genesis, seems to be an image of the reconciliation of the antinomies expressed by the diurnal and nocturnal facets of the Bachelardian philosophy. Expanding on the imagetic analysis of the "24-hour man" through a myth-analytical hermeneutics, we find the two semblances of Bachelard's philosophy configured, respectively, in the myths of Apollo-Prometheus and Dionysus.
\end{abstract}

\section{Keywords}

Gaston Bachelard - Epistemology - Metaphysics of poetic imagination - "24-hour man".

Contact:

Alexander de Freitas

Rua Padre Mororó, 348

09581-040-S. Caetano do Sul-SP

e-mail:xander@usp.br 
"Ora Lege Lege Lege Relege labora et invenies".

(14ª prancha Mutus Liber, 1677)

A inscrição acima, epígrafe da décima quarta - a penúltima - prancha do livro mudo da alquimia, o Mutus Liber, deve encerrar também a profissão-de-fé do estudioso da filosofia de Gaston Bachelard. "Reza, lê, lê, lê, relê, trabalha e encontrarás" anuncia a conclusão do trabalho alquímico - a obtenção da lapis philosophorum -, antecipando a redenção do artífice que se encontra representada na décima quinta prancha. A insígnia é emblemática do árduo e longo trabalho necessário à transmutação da matéria, simbolizada na necessidade de ler, ler, ler e, como se não bastasse, após a terceira leitura, reler -quantas vezes mais? Nessa obsessiva alusão à tenacidade do artífice frente aos estudos filosóficos, vamos encontrar ainda, ladeando as extremidades do atanor em que se encontra a epígrafe, o alquimista e sua soror mística, ambos levando a mão esquerda à boca em pedido de silêncio - segredo talvez.

Escolhemos essa epígrafe porque a décima quarta prancha do Mutus Liber é oráculo de imagens que prenuncia a aventura de quem ousa percorrer o labiríntico pensamento de Gaston Bachelard. Um homem - como ele próprio se autodenomina, de "dupla natureza" (2001a, p. 52) - dividido entre a cidade e o campo' ${ }^{1}$, a química e a alquimia, a epistemol-ogia da ciência e a metafísica da imaginação poética, vai fundar sua filosofia em um nó de antinomias que se harmonizam, como veremos, no homem complexo - o seu "homem das 24 horas". À semelhança das recomendações de profundidade e tenacidade necessárias a um bom leitor, a obra de Bachelard guarda ainda muitos segredos. Silenciada entre as visões parciais ora de historiadores da ciência, ora de críticos literários, a filosofia de Bachelard espera a aceitação da dualidade para ser desvelada. Dito de outro modo, a dualidade do homem bachelardiano, à luz dos segredos de ofício nos textos alquímicos, só se revelará àqueles que se dispuserem à leitura detida dos dois pólos do seu pensamento, o que significa, concretamente, percorrer as seis principais obras sobre epistemologia da ciência e mais nove sobre metafísica da imaginação poética. Estamos destacando aqui as seguintes obras sobre epistemologia da ciência: $O$ novo espírito científico (1934), A formação do espirito científico (1937), A filosofia do não (1940), $O$ racionalismo aplicado (1949), A atividade racionalista da física contemporânea (1951) e $O$ materialismo racional (1953). Sobre metafísica da imaginação poética, consideramos: A psicanálise do fogo (1938), A água e os sonhos (1942), $O$ ar e os sonhos (1943), A terra e os devaneios da vontade (1947), A terra e os devaneios do repouso (1947), A poética do espaço (1957), A poética do devaneio (1960), A chama de uma vela (1961) e, a última obra inacabada, Fragmentos de uma poética do fogo (1962).

Curiosamente, se atentarmos para a data de publicação das obras, podemos perceber que os dois perfis do pensamento diurno-noturno de Bachelard se alternam em ciclos: de 1928-1937 - obras dedicadas à filosofia da ciência; de 1942-1947 - obras dedicadas à imaginação material dos quatro elementos; de 1949-1953 retorno ao ciclo diurno; e finalmente, após 1957 - extensão do estudo da imaginação poética com a inclusão do método fenomenológico inaugurado pela iconoclasta " $A$ poética do espaço”. Se é que é possível precisar um tempo-espaço onde é máxima a tensão entre esses dois delineamentos da filosofia de Bachelard, arriscaríamos situá-lo no ambíguo e contraditório objetivo de "A psicanálise do fogo", de 1938:

Eis nosso objetivo: curar o espírito de suas felicidades, arrancá-lo do narcisismo que a evidência primeira proporciona, dar-lhe outras seguranças que não a posse, outras forças de con-

1. Mesmo no "exílio citadino" em Paris, Bachelard continuará expressando a nostalgia da vida no campo, herança de sua terra natal, Bar-sur-Aube, na região cognominada Champagne: "Quando em minha morada parisiense um vizinho crava pregos na parede tarde da noite, eu 'naturalizo' 0 barulho. Fiel ao meu método de tranqüilizar-me em relação a tudo o que me incomoda, imagino estar em minha casa de Dijon e digo a mim mesmo, achando natural tudo o que ouço: 'É o meu pica-pau que trabalha na minha acácia" (Bachelard, 2000, p. 110). Daí que 0 estilo de Bachelard é para Canguilhem (apud Pessanha, 1994, p. 6) um "estilo filosófico rural". 
vicção que não o calor e o entusiasmo; em suma, provas que não seriam em absoluto chamas! (Bachelard, 1999b, p. 6)

É o homem pensativo que queremos estudar aqui, o homem pensativo junto à lareira, na solidão, quando o fogo é brilhante, como uma consciência de solidão. (Bachelard, 1999b, p. 4)

Não é na obra em que se atinge o amplo domínio de um assunto, que as obscuridades do autor vão repercutir mais intensamente? Esse parece ser, precisamente, o caso de " $A$ psicanálise do fogo": de um lado, o objetivo de psicanalisar o discurso científico das imagens do fogo na tentativa de restabelecer a objetividade científica; de outro, a sedução do "fogocalor" conduzirá à metafísica de Bachelard, isto é, à entrega inevitável ao cenestésico, proclamando a vitória do materialismo imaginário quando o homem solitário sonha e recebe em seu corpo as carícias repousantes do fogo.

Harmonizando o dualismo do pensamento de Bachelard dividido entre o materialismo científico (face diurna) e o materialismo imaginário (face noturna), encontramos seu "homem das 24 horas". Esse homem "uni-dual", que se opõe e se complementa a cada 12 horas - andrógino que sutura os delineamentos das duas franjas do pensamento de Bachelard - é publicamente admitido na conferência "A natureza do racionalismo", proferida na Sociedade Francesa de Filosofia em 1950:

Se tivesse que fazer um plano geral das reflexões de um filósofo no Outono da sua vida, diria que tenho agora nostalgia de uma certa antropologia. Sendo mais claro, gostaria de discutir um tema que não é o de hoje, tema que chamaria "o homem das 24 horas". Parece-me, portanto, que se quisesse dar ao conjunto da antropologia suas bases filosóficas e metafísicas seria imprescindivel e também suficiente, descrever um homem durante as 24 horas de sua vida. (Bachelard, 1973, p. 54)

A opção de Bachelard pela escolha de um nó antropológico para realizar a sutura dos dois perfis do seu pensamento, da sua "dupla natureza" - ou as duas faces do seu "homem das 24 horas" - é confessada como "nostalgia de uma certa antropologia”, que é explicada em outra obra por meio da irônica - um dos principais recursos bachelardianos de cifrar o texto $^{2}$ - "antropologia completa":

Os problemas do materialismo colocar-se-ão tanto mais claramente quanto mais francamente efetuarmos uma separação completa entre a vida racional e a vida onírica, aceitando uma vida dupla, a do homem noturno e do homem diurno, dupla base de uma antropologia completa. (Bachelard, 1990c, p. 29)

\section{É essa "dupla vida”, é essa "antropolo-} gia completa", é esse "homem diurno e noturno" ou, o que vem dar no mesmo, o "homem das 24 horas" que se deve fixar como ponto de referência para análise e compreensão da dupla natureza tanto de Bachelard como de sua filosofia. Nesse sentido, este artigo tem como principal objetivo mostrar como dois pares de conceitos - o obstáculo epistemológico e a imaginação material; a psicanálise do conhecimento e o método fenomenológico - se opõem e se completam delineando uma face apolíneoprometeíca e outra dionisíaca, o que nos pareceu um exemplo privilegiado dos dois perfis do "homem das 24 horas" de Gaston Bachelard.

\section{A matéria diurna: Bachelard, o Apolo-Prometeu da epistemologia da ciência}

A filosofia da ciência de Bachelard é uma reflexão crítica sobre os modos de produção de conceitos e de teorias a partir da história

2. Outra herança do estilo alquímico na obra de Bachelard é o ciframento do texto através da ironia (do grego "ironéia", interrogação) manifesta por uma certa imprecisão e ambigüidade na caracterização dos conceitos: para evitar um acesso apressado e irrefletido ao seu pensamento? Durand (1988, p. 73) também comenta a utilização das ironias por Bachelard: "Há uma ironia soberana, um modo de jamais levar a sério aquilo (sic.) que se expõe ou que se argumenta, de modo a conferir ao argumento ou à intuição toda a gravidade necessária para convencer. Este elegante bom humor, essa leveza plena de modéstia dão às obras de Bachelard, como aos dizeres de Sócrates, uma perigosa eficácia de convicção". 
das idéias científicas, o que a caracteriza como uma análise epistemológica. Japiassú (1991) conceitua epistemologia como disciplina que, tomando as ciências como objeto de investigação, vai reagrupar a crítica do conhecimento científico, a filosofia da ciência e a história das idéias científicas. Relevante é a confusão entre os sentidos de epistemologia e filosofia da ciência que, segundo esse autor, decorre dos múltiplos significados que convergem para 0 termo epistemologia, tais como: "lógica da pesquisa científica", "teoria do conhecimento científico", "metodologia científica", "ciência da ciência”, que fazem com que a epistemologia se faça: "lógica”, "filosofia do conhecimento", "sociologia", "psicologia" e "história". Na tentativa de precisar essa noção, Japiassú (1991, p. 83) irá definir o campo de atuação da epistemologia com base no interesse dessa disciplina pela gênese e evolução do conhecimento científico:

[...] disciplina que toma por objeto não mais a ciência feita, uma ciência verdadeira de que deveríamos estabelecer as condições de possibilidade ou os títulos de legitimidade, mas as ciências em via de se fazerem, em seu processo de gênese, de formação e estruturação progressiva.

Como a filosofia da ciência de Bachelard é baseada na história das idéias científicas, acompanhando a evolução dos conhecimentos da química e da física, a partir do modus operandi das categorias filosóficas por ele criadas (realismo, empirismo, racionalismo e ultra-racionalismo), utilizaremos o termo filosofia da ciência com sentido de epistemologia, conforme sugestão de Japiassú.

Postulando períodos de ruptura epistemológica na história das idéias científicas, Bachelard (1999a, p. 11) reconhece basicamente três estágios pelos quais passaria o espírito científico. 0 primeiro, caracterizado pelo estado concreto em que "o espírito se apóia numa literatura filosófica que exalta a Natureza”, é chamado de realismo. Segue-se o estado concreto-abstrato caracterizado pelo "espírito que acrescenta à experiência física esquemas geométricos” que, lembrando o nascimento da experimentação, evidencia o empirismo. Por último, no estado abstrato, teríamos "o espírito adotando informações voluntariamente subtraídas à intuição do espaço real, voluntariamente desligadas da experiência imediata”, que configura o racionalismo.

Apesar da classificação em três categorias corresponder ao modus operandi do logos em períodos definidos da história das idéias científicas, Bachelard evidencia uma certa manutenção do espirito empirista e realista nos modos contemporâneos de pensar a ciência: trata-se da sua noção de obstáculo epistemológico. Desse modo, obstáculo epistemológico é definido por Bachelard como resistência à racionalização:

Lentidões e conflitos, que aparecem no âmago do próprio ato de conhecer, que causam inércia, estagnação e regressão [...]. E não se trata de considerar obstáculos externos como a complexidade e a fugacidade dos fenômenos, nem de incriminar a fragilidade dos sentidos e do espírito humano. (Bachelard, 1999a, p. 17)

Podemos perceber que a resistência à racionalização não é atributo da deficiência cognitiva do sujeito nem da impossibilidade de determinar o objeto: é na interação entre o sujeito e o objeto que o retardo e a lentidão parecem se manifestar. Mediando essa interação nefasta que retarda a chegada ao racionalismo, Bachelard irá pontuar o poder hipnótico da substância, da matéria alquímica, cuja potência de sedução caracteriza o obstáculo substancialista:

A substancialização de uma qualidade imediata percebida numa intuição direta pode entravar os futuros progressos do pensamento científico [...], pois tal substancialização permite uma explicação breve e peremptória. Falta-lhe o percurso teórico que obriga o espírito científico a criticar a sensação. De fato, para o espírito científico, todo fenômeno é um momento do pensamento teórico, um estágio do pensamento discursivo, um resultado preparado. (Bachelard, 1999a, p. 127) 
É justamente a polissemia da substância em seu poder de ancorar qualidades, a sedução e o maravilhamento exercido pela matéria, que vai constituir a noção de obstáculo substancialista na filosofia da ciência bachelardiana. Responsável pela lenta e longa transição do pensamento mágico-vitalista (alquímico) para o mecanicista na química, Bachelard vai considerar o substancialismo como obstáculo epistemológico, lembrando com propriedade: "a alquimia não prepara, de modo algum, a química: dificulta-a” (Bachelard, 1990c, p. 72).

É com objetivo de desalojar do discurso científico o perverso materialismo imaginário, mais ainda, é contra o poder de sedução do substancialismo que Bachelard publica: " $A$ formação do espírito científico: contribuição para uma psicanálise do conhecimento", aproveitando o subtítulo da obra para lançar seu projeto psicanalítico - instrumento metodológico que vai purificar o ímpeto racionalista da ciência do substancialismo. Como a função da psicanálise bachelardiana é a de deter, desagregar e proibir o devaneio materialista (Bachelard, 1999b), o obstáculo substancialista vai ocupar o lugar do inconsciente, organizando-se discursivamente a partir de expressões retiradas da psicanálise:

É o homem inteiro, com sua pesada carga de ancestralidade e de inconsciência, com toda a sua juventude confusa e contingente, que teria de ser levado em conta se quiséssemos medir os obstáculos que se põe ao conhecimento objetivo. (Bachelard, 1999a, p. 258)

Aqui aparece a noção de obstáculo epistemológico, ligada às palavras "ancestralidade", "inconsciência" e "juventude confusa", que traz à tona o conceito de inconsciente desenvolvido pela psicanálise. Essa substituição do conceito de obstáculo epistemológico e substancialismo por inconsciente do espírito científico é assumida explicitamente por Bachelard nas três passagens a seguir: "cumpre mostrar, na experiência científica, os vestígios da experiência infantil. Desse modo, estaremos autorizados a falar de um inconsciente do espírito científico" (1999b, p. 15); "não hesitaremos em invocar o instinto para destacar a justa resistência de certos obstáculos episte-mológicos" (1999a, p. 19); e ainda, "para caracterizar o fascínio da idéia de substância, será preciso procurar-lhe o princípio até no inconsciente" (1999a, p. 163).

É nessa derivação do substancialismo - do materialismo imaginário - em direção à noção de inconsciente, leitmotiv da psicanálise, que se revela o sentido dos termos "infantil", "trevas", "obscuro", "escuro", muito presentes no discurso bachelardiano quando se refere ao realismo ou à alquimia. É por meio dessa ambigüidade entre imagens da escuridão e do inconsciente que Bachelard esclarece: "mesmo na mente lúcida, há zonas obscuras, cavernas onde ainda existem sombras. Mesmo no novo homem permanecem vestígios do homem velho" (1999a, p. 10).

É no sentido inverso, isto é, de iluminar o inconsciente, de civilizá-lo, que a psicanálise, colocada como divisora de águas entre materialismo racional e o imaginário, explicará as metáforas da claridade no homem diurno, no homem superacordado, no homem em vigília de Bachelard. Apesar de encontrarmos uma derivação do conceito de obstáculo epistemológico e substancialismo em inconsciente em "A formação do espírito científico", é sobretudo em "A psicanálise do fogo" e em " $O$ materialismo racional" que se explicita a agressividade da noção de psicanálise bachelar-diana: "mediante uma suave tortura, a psicanálise deve fazer o sábio confessar seus motivos inconfessáveis" (Bachelard, 1999b, p. 91).

Fundando-se na agressividade, a psicanálise será o motivo que conduz à separação, a Spaltung ${ }^{3}$ na filosofia da ciência bachelardiana: "a psicanálise a que nos referimos é brutal, cirúrgica, é que ela separa num ápice as convic-

3. A Spaltung, conforme definida por Durand (1989, p. 129), se baseia no comportamento esquizofrênico de separar, de dissociar, de isolar: "0 sujeito apenas vê a cabeça, o pescoço, os braços. Aparecem continuamente nas descrições termos como cortado, partido, separado, dividido em dois, fragmentado [...], que põem em evidência, até a obsessão, o 'complexo do gládio'”. 
ções inconscientes das convicções racionais” (Bachelard, 1990c, p. 28). Como havíamos indicado, a psicanálise assumirá o fio de um gládio cortante que vai separar "joio do trigo". Por isso mesmo, é sempre necessário à atividade científica manter a vigilância de "uma psicanálise persistente para situar a filosofia química no clima de racionalidade" (Bachelard, 1990c, p. 62).

É no sentido de purificar e reprimir o domínio das imagens e símbolos gerados pelo substancialismo, ou o que dá no mesmo, pelo inconsciente, que vislumbramos a mensagem da psicanálise na obra bachelardiana. É assim que nas obras de epistemologia da ciência de Bachelard, enquanto o obstáculo substancialista toma forma de inconsciente do espirito científico, a psicanálise se revela como catarse e recalque:

0 recalque é uma atividade normal, uma atividade útil e, mais ainda, uma atividade alegre. Não há pensamento científico sem recalque. 0 recalque está na origem do pensamento atento, reflexivo, abstrato. Todo pensamento coerente é construído sobre um sistema de inibições sólidas e claras. (Bachelard, 1999b, p. 146)

Mais uma vez é possível evidenciar aqui a temática do controle, da repressão, do refreamento e da disciplina, condição sine qua non para o nascimento do espírito científico na epistemologia de Bachelard. Se compreendermos essa "vigilância epistemológica" como núcleo organizador da filosofia da ciência de Bachelard, poderemos estabelecer uma homologia semântica desta com o mito de Apolo por meio da prescrição de moderação, de comedimento, de ética rigorosa, representados nas máximas do Oráculo de Delfos: o "gnôthi s'autón”, conhecete a ti mesmo e o "medèn ágan", nada em demasia (Brandão, 2002, p. 132). Congruente à intenção da epistemologia de Bachelard, o apelo do Oráculo de Delfos para o "métron", para a medida que cada um deve ter, vai representar o exorcismo do conhecimento oculto, imagético, imaginário, rumo a uma "linguagem vigiada" que se desenha na filosofia da ciência bachelardiana mediante as noções de psicanálise e recalque. É justamente esse apelo ao métron que faz Brandão (2002, p. 94) considerar Apolo como o "deus kathársios, 'o purificador', por excelência".

Porém, é sobretudo pelo motivo heróico, solar e diurno - é matando a potência ctônia Píton que Apolo se faz senhor do Oráculo de Delfos - que é preciso compreender o semantismo apolíneo na epistemologia bachelardiana. É essa configuração purificadora personificada por Apolo - que estabelece a supremacia das potências uranianas sobre as ctônias - que vai constelar mais propriamente com o ideal catártico da psicanálise de Bachelard. É assim que a arma utilizada por Apolo para matar a serpente Píton é o arco e a flecha que, no plano simbólico, significa: "o desapego da viscosidade do concreto e do imediato" (Brandão, 2002, p. 94).

É também pela metáfora "Apolo-deussol”, significando claridade, luz, dia, que é possível aproximar o mito de Apolo ao pressuposto diurno do discurso da ciência na epistemologia de Bachelard. É nesse sentido que o fogo roubado por Prometeu para iluminar a humanidade vai convergir com o ideal de salvação presente em " $A$ formação do espírito científico" e em "A psicanálise do fogo". Se entendermos, como Durand (1989, p. 120), que o fogo é "prolongamento ígneo da luz", compreenderemos que é como luz que o fogo de Prometeu anima a epistemologia de Bachelard: é a emanação de luz que elevará a consciência do homem, iluminando a estagnação do espírito científico, associada ao realismo e empirismo. Daí que Prometeu, consoante a etimologia, segundo Brandão (2001, p. 166), deriva de "pró", antes e "manthánein", aprender, saber, perceber, significando aquele que é "pré-vidente", que percebe de antemão.

Por último, se lembrarmos que a luz, de acordo com Durand ${ }^{4}$ (1989, p. 111), "tem tendência para se tornar raio ou gládio”, que irá "provar facilmente um belicoso dogmatismo da

4. Bachelard, antes de Durand, mostra a homologia semântica entre a luz e a purificação: "Às vezes o fogo brilha sem queimar; então seu valor é todo pureza", e também, "a luz não é apenas um símbolo, mas um agente de pureza" (Bachelard, 1999b, p. 156). 
representação", poderemos situar na epistemologia bachelardiana, um ideal hiperbólico de purificação, que incita à guerra. Nesse sentido de "fogo-luz-gládio", que remete ao simbolismo diairético ${ }^{5}$ de Durand, é que devemos entender a força de expressão bélica das armas escolhidas por Bachelard para luta contra o inconsciente materialista: "é necessário devolver à razão sua função turbulenta e agressiva” (Bachelard, 1973, p. 13), "a psicanálise a que nos referimos é brutal, cirúrgica” (Bachelard, 1990c, p. 28) e ainda "a idéia científica muito usual [...] perde aos poucos seu vetor de abstração, sua afiada ponta abstrata" (Bachelard, 1999a, p. 19). Assim, a razão turbulenta e agressiva, a psicanálise brutal e cirúrgica, a ponta afiada da abstração vão lembrar a batalha contra os simbolos das trevas, a flecha cortante com que Apolo mata Píton e o bico da águia que devora o fígado - reservatório de bílis negra, inconsciente de Prometeu.

Não é por outro motivo para além da obsessão da epistemologia de Bachelard pela luz, símbolo da iluminação das trevas, da lucidez, da catarse e da purificação armada nos mitos de Apolo e Prometeu, que se associa ao filósofo como pensador da ciência, o epíteto "Bachelard diurno ${ }^{6}$ ". Em tom confessional:

Quero limitar-me ao homem em vigília, ao homem super acordado, ao homem que eu denominaria precisamente "o homem racionalista" [...]. Quando me ocupo das matemáticas o faço precisamente nas horas do meu dia, naquelas em que há o máximo de claridade, que seria creio, o caráter fundamental do homem racionalista. (Bachelard, 1973, p. 54)

\section{A matéria noturna: Bachelard, o Dioniso da metafísica da imaginação poética}

Se a "matéria diurna" se organiza discursivamente por uma linguagem vigiada, representada pelo "medèn ágan" apolíneo e pelo suplício de Prometeu, evidenciaremos nesta seção a inversão do valor nefasto atribuído ao adjetivo, quando entra em cena a "matéria noturna”. De fato, há na filosofia de Bachelard uma dupla valorização gramatical do adjetivo: de leitmotiv do obstáculo epistemológico na face diurna ao poder de traduzir o sensualismo - fervilhante - da matéria: "dê qualidade às coisas, dê, do fundo do seu coração, o poder justo aos seres agentes e o universo resplandecerá" (Bachelard, 1989, p. 95).

Alijado do papel de obstáculo epistemológico que induz ao raciocínio "concreto", "imediato", "breve" e "peremptório", o adjetivo vai dinamizar todo o imaginário material, intermediando a matéria à sensação do sonhador: “a maneira pela qual amamos uma substância, pela qual enaltecemos a qualidade, manifesta uma reatividade de todo o nosso ser" (Bachelard, 1990a, p. 62). Por isso, podemos dizer que, na gramática do imaginário, o adjetivo vai traduzir a emoção do ser - mais propriamente na metafísica poética de Bachelard, a emoção cenestésica do ser em contato com a matéria: “quem não sente, por exemplo, uma repugnância especial, irracional, inconsciente, direta pelo rio sujo?" (Bachelard, 1998, p. 143). 0 obstáculo epistemológico substancialista precisa do "sujo" - como também do "fresco" e "limpo" - para evocar o materialismo noturno da água.

Se, na metafísica de Bachelard, o adjetivo vai representar a força propulsora da imaginação poética, invertendo a ação maldita que situamos na epistemologia da ciência, outra inversão de valorização será evidenciada pelo conceito de substância. Revertendo o valor negativo do poder da matéria em ancorar sensações, isto é, indo da "kátharsis" ao "ekstasis",

5. Reconhecendo o isomorfismo entre imagens ascensionais e luminosas e a "transcendência armada", Durand (1989) vai postular os símbolos diairéticos associados à separação, ao corte, à distinção, sendo o gládio de ouro, o ícone representativo do Regime diurno de imagem: "é com efeito 0 gesto diairético que parece subtender todo este Regime de representação, e parece mesmo que se, reflexologicamente, nos elevamos primeiro é para termos a faculdade de melhor separar, de melhor discernir [...]. Podese dizer que a actualização do Regime Diurno de imagem se faz pelo gládio e pelas atitudes imaginárias diairéticas" (p. 124).

6. Pessanha (1994, p. 5) é o primeiro pensador brasileiro a utilizar o termo "Bachelard diurno" para caracterizar a vertente científica do filósofo fundada na "interminável aventura de clarificação e correção de conceitos", chegando a fazer referência à relação entre Bachelard diurno e Apolo: "Bachelard diurno da epistemologia, do apolíneo reino dos conceitos" (p. 9). 
o indesejável obstáculo substancialista vai se converter em "imagens da matéria, imagens diretas da matéria (Bachelard, 1998, p. 2), por meio do conceito de imaginação material ${ }^{7}$ :

Quando se encontrou a raiz substancial da qualidade poética, quando se encontrou realmente a matéria do adjetivo, a matéria sobre a qual trabalha a imaginação material, todas as metáforas bem enraizadas desenvolvem-se por si mesmas. (Bachelard, 1998, p. 34)

A inversão de valorização do adjetivo e da matéria nas duas frentes do pensamento de Bachelard dá concretude tanto à "dupla natureza", à "antropologia completa", como ao seu "homem das 24 horas". É importante insistir em que a metafísica poética é uma alquimização da relação do homem com a matéria que havia sido condenada à purificação pelo ímpeto da psicanálise na epistemologia. Desse modo, há uma revitalização do materialismo imaginário expulso da ciência racionalista à medida que o poder de fixar, coagular, ancorar, estabilizar o devaneio é restituído à matéria mediante a noção de imaginação material:

[...] o imaginário não encontra suas raízes profundas e nutritivas nas imagens, a princípio ele tem necessidade de uma presença mais próxima, mais envolvente, mais material. (Bachelard, 1998, p. 126)

Revisitando mais um lema alquímico, o "fac fixum volatile" - que pode ser lido tanto no sentido de "faça fixo o volátil", como "faça volátil o fixo" -, Bachelard vai definir sua noção de imaginação material a partir da fixação do devaneio realizada pela substância ou, mais fidedignamente, como aparece nas suas cinco primeiras obras sobre metafísica da imaginação poética, por meio de um dos quatros elementos da física aristotélica (água, ar, terra e fogo):

Permitimo-nos lembrar aqui alguns livrinhos recentes em que estudamos, sob o nome de imaginação material essa espantosa necessidade de "penetração" que, para além das seduções da imaginação das formas, vai pensar a matéria, sonhar a matéria, viver na matéria, ou então - o que vem dar no mesmo - materializar o imaginário. (Bachelard, 2001c, p. 7-8)

Apesar do viés psicologista - que enxerga a matéria como substrato de projeção do inconsciente -, Jung em sua obra "Psicologia e alquimia" reforça a idéia da matéria como estabilizadora do imaginário presente na metafísica bachelardiana, explicando assim o poder da imaginação material em produzir imagens. É assim que a metafísica de Bachelard vai trazer de volta o modus operandi da alquimia: "devido à projeção há uma identidade inconsciente entre a psique do alquimista e a substância arcana" (Jung, 1994, p. 279), de modo que, "a base do ‘opus' é a matéria prima” (p. 329).

Mais céptico a respeito da função fixadora da matéria para o devaneio, Gilbert Durand - para quem o imaginário é relação dialógica e recursiva do homem com o meio - vai deslocar a relação da “matéria-imaginação" para a relação tríplice "matéria-sensação-imaginação” (Durand, 1989, p. 29). Daí podermos situar a imaginação material como síntese da sensação - cenestésica, etimologicamente do grego "koinos", difuso e "aisthesis", sensação - do homem com a matéria:

[...] a água, a terra, o fogo e o ar e todos os seus derivados poéticos são o lugar mais comum desse império onde o imaginário vem se enxertar diretamente na sensação" (Durand, 1989, p. 68-69)

Escamoteando propositadamente a discussão da causalidade da imaginação material, o que instauraria a psicanálise em território protegido do materialismo imaginário, Bachelard, sem

7. É em "A água e os sonhos" que aparece, primeiramente, a diferenciação entre a imaginação de causa material considerada materialismo imaginário diante da imaginação formal da ciência: "Expressando-nos filosoficamente desde já, poderíamos distinguir duas imaginações: uma imaginação que dá vida à causa formal e uma imaginação que dá vida à causa material; ou, mais brevemente, a imaginação formal e a imaginação material" (Bachelard, 1998, p. 1). 
receio da contradição, vai afirmar a mediação material do sujeito com o mundo, mediante a imaginação material: “a imaginação é devolvida à sua função vital que é valorizar as trocas materiais entre o homem e as coisas" (Bachelard, 1990a, p. 51).

Por fim, a última e talvez mais importante revolução copernicana, que se circunscreve na passagem da epistemologia para a metafísica de Bachelard, é a conversão da psicanálise à fenomenologia. Depois de publicar as cinco obras sobre os quatro elementos materiais, Bachelard vai lançar, em " $A$ poética do espaço”, o referencial fenomenológico-compreensivo para aprofundar a discussão sobre a gênese da imagem poética, o que, aliás, justifica considerarmos essa vertente do seu pensamento de "metafísica da imaginação poética":

É necessário estar presente, presente à imagem no minuto da imagem: se há uma filosofia da poesia, ela deve nascer e renascer por ocasião de um verso dominante, na adesão total a uma imagem isolada, muito precisamente no próprio êxtase da novidade da imagem. (Bachelard, 2000, p. 1)

Desembaraçando-se da salutar abstração que prevenia o discurso científico da invasão das imagens materiais, convertendo o substancialismo maldito em "adesão total a uma imagem" e, mais, livrando-se dos grilhões da vigilância psicanalítica por meio do mergulho no "êxtase da novidade da imagem", Bachelard vai propor seu método fenomenológico como arrebatamento, epifania, espanto - em uma palavra: êxtase, do latim "extasis"; de "ex", fora e "stasis", estado - do sujeito quando em contato com a imagem poética:

Todos os meus livros sobre o devaneio das imagens materiais ligadas aos quatro elementos tradicionais poderiam ser livros de começo. [...] Neles eu não defendia nenhuma tese, não partia de nenhuma hipótese, queria viver muito simplesmente no maravilhamento das imagens novas. (Bachelard, 1990b, p. 32)
É precisamente essa mobilização empática (de "en" + "pathos", o sentir por dentro) do sujeito em "ex-stasis", isto é, que deixa seu "si mesmo" para se entregar à imagem poética nessa epifania da imagem - que melhor se traduz o método fenomenológico de Bachelard:

Para esclarecer filosoficamente o problema da imagem poética, é preciso chegar a uma fenomenologia da imaginação. Esta seria um estudo do fenômeno da imagem poética quando a imaginação emerge na consciência como um produto direto do coração, da alma, do ser do homem tomado em sua atualidade. $(2000$, p. 2$)$

Nesse sentido, "como um produto direto do coração e da alma”, a fenomenologia bachelardiana prescreve um mergulho na emoção - experiência essa que reside na ativação de nosso eu total (Spolin, 1987, p. 215) - condição sine qua non de criação e decodificação da imagem poética. Assim, a fenomenologia de Bachelard é uma filosofia da entrega, da necessidade de envolvimento íntimo do leitor com a dinâmica despertada pela imagem: "já não nos parece um paradoxo dizer que o sujeito falante está por inteiro numa imagem poética, pois se ele não se entregar a ela sem reservas não entrará no espaço poético da imagem" (Bachelard, 2000, p. 12).

Opondo-se diametralmente às imagens de corte, separação e "purificação armada" da psicanálise na epistemologia, a profissão-de-fé do método fenomenológico de Bachelard "estabelece a plenitude da imagem” (Durand, 1988, p. 68), utilizando a via da emoção, do maravilhamento, do ekstasis como intermediadores da relação dialógica da imagem com o sujeito. Fazendo compreender o que Souza Santos (1989, p. 41) aponta como "ruptura com a ruptura epistemo-lógica”, o método fenomenológico, ressaltando o dinamismo criador da imagem, vai execrar a psicanálise como explicação para o nascimento da imagem poética:

As doutrinas timidamente causais, como a psicologia, ou fortemente causais como a psicaná- 
lise, não podem determinar a ontologia do poético. Nada prepara uma imagem poética: nem a cultura, no modo literário, nem a percepção, no modo psicológico. (Bachelard, 2000, p. 8)

Essa afirmação do indeterminismo causal da gênese da poética é garantia de proteção do alijado poder criador substancialista na metafísica da imaginação bachelardiana. Assim, em "A poética do espaço", Bachelard rompe, definitivamente, com a psicanálise, condenando a busca de quaisquer antecedentes - sejam causas psicológicas ou sofrimentos e infortúnios do poeta - que expliquem o nascimento da imagem poética. É nesse contexto que se deve compreender a emblemática frase: "a imagem poética não é eco de um passado” (Bachelard, 2000, p. 2).

No entanto, vejamos que, já na primeira obra sobre o devaneio material - em " $A$ água e os sonhos"-, Bachelard renuncia à psicanálise das imagens da água. 0 motivo é o mesmo que vimos apontando aqui: a adesão irracional à imagem, a potência criadora do inconsciente - lugar das "preferências indestrutiveis" (Bachelard, 1999a, p. 163) - apaga a claridade da fatigada retina que vela a vigilância do homem racionalista:

Reencontro sempre a mesma melancolia diante das águas dormentes, uma melancolia muito especial que tem a cor de um charco numa floresta úmida, uma melancolia sem opressão, sonhadora, lenta, calma. Um detalhe ínfimo da vida das águas converte-se freqüentemente, para mim, em símbolo psicológico essencial. [...] Não posso sentar perto de um riacho sem cair num devaneio profundo, sem rever a minha ventura... (Bachelard, 1998, p. 8-9)

Pelo que foi dito até aqui, é sempre a sensação, dinamizada pela adjetivação, impregnada de matéria e ébria de maravilhamento, leitmotiv de uma abordagem fenomenológicocompreensiva, que parece ser o nó górdio da metafísica da imaginação poética de Bachelard.
É essa pregnância da "função sensitiva" - do apelo ao sentir - a emoção poética que aproxima a metafísica de Bachelard ao mito de Dioniso, isso porque o mito deste nos revela um deus da metamorphósis, um deus que gera transformação por meio da epifania, do ekstasis, isto é, de uma catarse às avessas. Assim, a partir da narrativa de Dioniso, verificaremos a inversão de valores do mito de Apolo e Prometeu, isto é, a substituição do "medèn ágan" pelo "enthusiasmós", do iluminismo científico pela imagem poética, da razão pela emoção, da disciplina pelo êxtase, do homo sapiens pelo homo demens.

Se lembrarmos que, nas Anthestéria festa das flores, a grande festa dionisiaca e a mais antiga delas -, a embriaguez, as danças e a euforia causadas pela bebida sagrada oferecida pelo deus do vinho levavam os participantes a experimentar uma realidade fora de si, fazendo-os alcançar uma reintegração orgiástica e mística, poderemos compreender que a metamorphósis dionisíaca não é mediada pela kátharsis, mas pelo ekstasis.

É no abandono da condição humana pela transposição do "métron", "da medida”, por meio dos rituais de bebedeira nas Antestérias, que se manifesta o sentido sagrado no mito de Dioniso. Assiste-se então à ultrapassagem do profano pela hierofania, quando "algo de sagrado se nos revela” (Eliade, 2001, p. 17). Nesse sentido de "ekstasis" como "sair de si" para um mergulho em Dioniso, esclarece-se etimologicamente o sentido de "enthusiasmós", de "éntheos", isto é, "animado de um transporte divino", que procede de "en", dentro, no âmago e de "théos", deus (Brandão, 2002, p. 136). Como repetimos diversas vezes, é literalmente esse entusiasmo que Bachelard propõe como mediador do par "imagem-sujeito" em sua metafísica da imaginação poética:

Para receber diretamente a virtude de uma imagem isolada, a fenomenologia parece-me agora mais favorável que a psicanálise, pois a fenomenologia nos pede exatamente para assumirmos nós próprios sem crítica, com entusias- 
mo, essa imagem. (Bachelard, 2000, p. 175, grifos nossos)

É no caminho do "enthusiasmós" que a imagem poética é "a explosão de uma imagem" (Bachelard, 2000, p. 2) ou "a grande lareira de palavras indisciplinadas onde se consome o ser" (Bachelard, 1990b, p. 35). É no caminho do ekstasis que o suplício de Prometeu caro à atividade racionalista vai se converter no " $h o-$ mem feliz": "a imagem poética está sob o signo de um novo ser. Este novo ser é o homem feliz" (Bachelard, 2000, p. 13).

Há mesmo uma referência direta à embriaguez, consagrada a Dioniso, em relação à imagem poética libertada pela fenomenologia: "em sua embriaguez da linguagem nova o poeta abandona a linguagem explicativa" (Bachelard, 1990b, p. 45). Em outra obra, comentando a embriaguez poética, Bachelard dá crédito diretamente a Dioniso: "a embriaguez lírica se apresenta apenas como uma paródia da embriaguez dionisíaca" (1990a, p. 62). Em outra passagem, a relação da metafísica de Bachelard com o mito de Dioniso acontece por meio de expressões próprias ao ritual sagrado do deus do vinho: "com a poesia, a imaginação coloca-se na margem em que precisamente a função do irreal vem arrebatar ou inquietar - sempre despertar - o ser adormecido em seus automatismos" (2000, p. 18).

0 arrebatamento não é sinônimo de êxtase e o inquietar não sugere a imagem da "órguia”, agitação incontrolável pela posse do divino? Às vezes, o êxtase, deriva para "espanto" com a conotação ambivalente de admiração e pavor que caracteriza o mysterium tremendum, isto é, o fascínio e o terror pela revelação do sagrado: "no momento em que vive o seu espanto, o ser maravilhado faz abstração de todo um universo em proveito de um traço de fogo, de um movimento que canta" (Bachelard, 2001c, p. 66).

Por todas as analogias semânticas - e aqui, muitas vezes textuais - entre o mito de Dioniso e a metafísica poética de Bachelard, podemos circunscrever como núcleo organizador dessa outra vertente do seu pensamento, a expe- rimentação extasiada do mundo, que vimos conduzir tanto o conceito de imaginação material como de método fenomenológico. Nesse caso, a transcendência não é alcançada pela catarse como no mito de Prometeu e Apolo, mas à luz do êxtase do homo dionysiacus, isto é, por meio da emoção que repercute intimamente. Esse tom dionisíaco de animação sensível que rege a metafísica poética de Bachelard, invertendo a Spaltung da epistemologia em Einfühlung (do alemão, empatia), justifica o adjetivo "noturno" que atribuímos à matéria nesta seção.

\section{O “homem das 24 horas" e a Pitonisa: a coexistência de Apolo e Dioniso}

Apesar de o "homem das 24 horas" estar restrito a uma citação que não teve ressonância em outras obras de Bachelard, quisemos defender sua existência neste artigo, porque acreditamos que essa imagem recursivamente alternada do dia e da noite serve de metáfora epistemológica para compreendermos a totalidade do pensamento de Bachelard. A lacuna de uma existência bem fundamentada do "homem das 24 horas" nas obras de Bachelard levou-nos a investigar, neste artigo, quatro noções opostas, concorrentes e complementares - o obstáculo substancialista e a imaginação material; a psicanálise do conhecimento e o método feno-menológico - com objetivo de fazer nascer um "homem das 24 horas" de existência, a priori, muito efêmera.

Por último, gostariamos de mostrar que também nos mitos que escolhemos como organizadores das duas vertentes do pensamento de Bachelard, há uma harmonização de contrários por meio da figura da Pitonisa - a sacerdotisa do mito de Apolo -, o que reforçaria, uma vez mais, agora, partindo de um referencial "mito-dológico" (Durand, 1982), a importância da imagem do "homem das 24 horas" como conciliador do dois perfis do pensamento bachelardiano.

Lembremos que o evento heróico que faz de Apolo o senhor do Oráculo de Delfos é a morte da potência ctônia Píton que vai re- 
nascer na figura da Pitonisa ou Pítia - nome da sacerdotisa intérprete de Apolo que, em estado de êxtase e entusiasmo, respondia às consultas que lhe eram feitas:

A Pítia, após beber água da fonte Cassótis, que dizem, corria no ádyton, sentava-se na trípode e tocava no omphálos, que ficava junto àquela. Em seguida, mastigando folhas de loureiro, respirava as exalações (pneúmata) que proviriam de uma fenda do solo (...), entrava em êxtase e entusiasmo; "possuída de Apolo", balbuciava palavras entrecortadas, que eram recolhidas pelos Sacerdotes. (Brandão, 2002, p. 98)

Essa conciliação “Apolo-Dioniso", realizada pela Pitonisa por meio da harmonização entre "mantéia" e "manía", isto é, entre o poder de adivinhação concedido à Pitonisa por
Apolo - deus mântico por excelência - e a mania, loucura sagrada, inseparável de Dioniso, é também comentada por Brandão (2002):

Talvez se pudesse compreender a Pitonisa como uma espécie de conciliação ctônio-dionisíacoapolínea. Seja como for, acreditando-se que a Pítia entrasse em êxtase e entusiasmo, a "técnica" seria dionisíaca, mas o "efeito" era apolíneo. (p. 100)

Do mesmo modo que a Pitonisa justapõe Apolo e Dioniso, pois se utiliza da mania dionisíaca para um "efeito apolíneo", o "homem das 24 horas" concilia a uni-dualidade do pensamento "diurno" - prometeíco-apolíneo - e "noturno" - dionisíaco - de Bachelard, a tal ponto que esses mitos parecem consolidar de modo exemplar, tanto quanto o "homem das 24 horas", os dois perfis da filosofia de Gaston Bachelard.

\section{Referências bibliográficas}

BACHELARD, G. L'Activité racionaliste de la physique contemporaine. 3. ed. Paris: PUF, 1965.

0 novo espírito científico. Rio de Janeiro: Tempo Brasileiro, 1968.

El compromiso racionalista. Buenos Aires: Siglo Veintiuno Editores, 1973.

A filosofia do não: filosofia do novo espírito científico. São Paulo: Abril Cultural, 1974. p.161-245. Col. Os Pensadores.

0 racionalismo aplicado. Rio de Janeiro: Zahar, 1977.

A chama de uma vela. Rio de Janeiro: Bertrand Brasil, 1989.

A terra e os devaneios do repouso: ensaio sobre as imagens da intimidade. São Paulo: Martins Fontes, 1990a.

Fragmentos de uma poética do fogo. São Paulo: Brasiliense, 1990b.

0 materialismo racional. Lisboa: Edições 70, 1990c.

A água e os sonhos: ensaio sobre a imaginação da matéria. São Paulo: Martins Fontes, 1998. 1999a.

A formação do espírito científico: contribuição para uma psicanálise do conhecimento. Rio de Janeiro: Contraponto,

A psicanálise do fogo. 2. ed. São Paulo: Martins Fontes, 1999b.

A poética do espaço. São Paulo: Martins Fontes, 2000. 
A poética do devaneio. São Paulo: Martins Fontes, 2001a.

A terra e os devaneios da vontade: ensaio sobre a imaginação das forças. 2. ed. São Paulo: Martins Fontes, 2001b.

0 ar e os sonhos: ensaio sobre a imaginação do movimento. 2. ed. São Paulo: Martins Fontes, 2001c.

BRANDÃO, J. S. Mitologia grega. v. 1. 16. ed. Petrópolis: Vozes, 2001.

Mitologia grega. v. 2. 13. ed. Petrópolis: Vozes, 2002.

DURAND, G. Mito, símbolo e mitodologia. Lisboa: Editorial Presença, 1982.

A imaginação simbólica. São Paulo: Cultrix/EDUSP, 1988.

As estruturas antropológicas do imaginário: introdução à arquetipologia geral. Lisboa: Editorial Presença, 1989.

ELIADE, M. 0 sagrado e o profano. São Paulo: Martins Fontes, 2001.

JAPIASSÚ, H. Dicionário básico de filosofia. 2. ed. Rio de Janeiro: Jorge Zahar, 1991.

JUNG, C. G. Psicologia e alquimia. 2. ed. Petrópolis: Vozes, 1994.

MUTUS LIBER: o livro mudo da alquimia. São Paulo: Attar, 1995.

PESSANHA, J. A. M. Bachelard: as asas da imaginação. In: BACHELARD, G. 0 direito de sonhar. 4.ed. Rio de Janeiro: Bertrand do Brasil, 1994. p. 5-31.

SOUZA SANTOS, B. Introdução a uma ciência pós-moderna. 3. ed. Rio de Janeiro: Graal, 1989.

SPOLIN, V. Improvisação para o teatro. São Paulo: Perspectiva, 1987.

Recebido em 15.03.05

Modificado em 09.06.05

Aprovado em 01.07.05

Alexander de Freitas é mestre em Ensino de Ciências pelo Programa Interunidades em Ensino de Ciências (Instituto de Química - Instituto de Física - Faculdade de Educação) da Universidade de São Paulo, doutorando do Programa de PósGraduação em Educação da Faculdade de Educação da Universidade de São Paulo. 